\title{
Penerapan Standar Akuntansi Keuangan Entitas Tanpa Akuntabilitas Publik (SAK ETAP) Pada PT. Aira Nusantara Indah
}

\author{
Friska Frilisia ${ }^{1}$ \\ I Gde Ary Wirajaya ${ }^{2}$
}

${ }^{1}$ Fakultas Ekonomi dan Bisnis Universitas Udayana (Unud), Bali, Indonesia email: friskafrilisia@gmail.com / Telp: +6281246052621

${ }^{2}$ Fakultas Ekonomi dan Bisnis Universitas Udayana (Unud), Bali, Indonesia

\begin{abstract}
ABSTRAK
Tujuan penelitian ini adalah untuk mengetahui penyusunan dan penyajian laporan keuangan berdasarkan SAK ETAP pada PT. Aira Nusantara Indah. Penelitian ini menggunakan pendekatan kualitatif dengan metode studi kasus. Langkah - langkah yang dilakukan untuk memperoleh data dan informasi adalah dengan observasi, dokumentasi, dan wawancara. Hasil penelitian ini menunjukkan bahwa laporan keuangan yang dibuat dan disajikan oleh PT. Aira Nusantara Indah belum sepenuhnya sesuai dengan SAK ETAP. PT. Aira Nusantara Indah hanya melakukan proses pencatatan dengan membuat jurnal khusus yang terdiri atas catatan penerimaan dan pengeluaran kas, catatan piutang, catatan penjualan, dan kartu persediaan barang dagangan, namun catatan yang dibuat oleh perusahaan ini belum sepenuhnya efektif dan efisien. Pengakuan dan pengukuran akun-akun laporan posisi keuangan dan akun-akun laba rugi sebagian besar sudah sesuai dengan SAK ETAP. Ketidaksesuaian dalam penyusunan dan penyajian laporan keuangan ini dikarenakan terbatasnya pengetahuan pemilik dan sumber daya manusia yang dimiliki oleh perusahaan.
\end{abstract}

Kata kunci: laporan keuangan, SAK ETAP, UMKM.

\begin{abstract}
The purpose of this study is to determine the preparation and presentation of financial statements based on SAK ETAP at PT. Aira Nusantara Indah. This research uses qualitative approach with case study method. The steps taken to obtain data and information by observation, documentation, and interview. The results of this study indicate the financial statements presented by PT. Aira Nusantara Indah hasn't fully complied with SAK ETAP. PT. Aira Nusantara Indah only performs the recording process by creating special journal consisting of records of cash receipts and disbursements, accounts receivable records, sales records, and merchandise inventory cards, but the records made by this company haven't been fully effective and efficient. Recognition and measurement of accounts in financial statement position and profit and loss are fully compliance with SAK ETAP. Non-conformance in preparing and presenting financial statements is due to limited knowledge of owners and human resources owned by the company.
\end{abstract}

.Keywords: financial report, SAK ETAP, SMEs. 


\section{PENDAHULUAN}

Peranan usaha mikro, kecil, dan menengah (UMKM) memiliki pengaruh yang sangat besar terhadap jumlah pendapatan negara. Tercatat jumlah UKM di Negara-negara maju dapat mencapai $90 \%$ dari total seluruh unit usaha, dan mampu menyerap sebanyak $2 / 3$ tenaga kerja dari jumlah pengangguran yang ada (Baas dan Schrooten, 2005). Pentingnya usaha kecil dan menengah (UKM) di dalam pembangunan ekonomi suatu negara adalah hal yang tak terbantahkan. Di sebagian besar negara, UKM mengisi sebagian besar jumlah perusahaan, jumlah pekerjaan, hingga pendapatan penjualan dan ekspor. Mereka juga dianggap sebagai sumber utama pekerjaan dan inovasi (Thang dan Quang, 2005). Disisi lain, perkembangan usaha kecil dan menengah seringkali menghadapi kendala baik internal maupun eksternal.

Kendala internal terutama berkaitan dengan kualitas sumberdaya manusia (Rosadi, 2011). Salah satu kelemahan UKM yang banyak ditemui adalah lemahnya pelaporan aktifitas bisnis secara kuantitatif. Praktik akuntansi keuangan pada UKM dinilai masih rendah dan memiliki banyak kelemahan (Wahdini dan Suhairi, 2006). Rendahnya penyusunan laporan keuangan disebabkan karena tidak adanya peraturan yang mewajibkan penyusunan laporan keuangan bagi UMKM (Raharjo, 1993 dalam Pradipta, 2015). Permasalahan lain yang dihadapi oleh usaha kecil adalah keterbatasan modal khususnya untuk modal kerja, dimana penyusunan laporan keuangan yang masih sangat rendah ini merupakan salah satu penyebab terjadinya masalah permodalan (Tambunan, 2012). 
Martani (2012) dalam Sakti (2017), mengungkapkan bahwa laporan keuangan merupakan informasi bagi penggunanya, terutama pemilik perusahaan, investor, kreditur, dan juga manajemen untuk mengambil keputusan-keputusan terkait perusahaan di masa mendatang. Menurut praktik akuntansi yang berlaku umum, tujuan laporan keuangan adalah memberikan informasi yang berguna kepada kelompok pengguna utama dari laporan keuangan, terlepas dari ukuran entitasnya (van Wyk dan Rossouw, 2009). Tidak menerapkan dan tidak menguasai sisitem keuangan atau pembukuan yang memadai menjadi salah satu kelemahan usaha kecil di Indonesia. Hal ini dikarenakan keterbatasan pengetahuan mengenai akuntansi, rumitnya proses akuntansi, dan anggapan bahwa laporan keuangan bukanlah hal yang penting bagi UMKM (Said, 2009 dalam Rudiantoro, 2012).

Hal ini sejalan dengan penelitian yang dilakukan oleh Lucas, et al. (2013) yang menyatakan bahwa kegagalan atau kinerja yang kurang baik dari UKM sering kali disebabkan oleh ketidaktepatan dalam menggunakan alat akuntansi manajemen yang sesuai. Padahal dengan adanya akuntansi yang memadai, pengusaha UMKM dapat memenuhi persyaratan dalam pengajuan kredit, seperti pembuatan laporan keuangan, dimana hal ini merupakan hal yang sangat penting bagi kelangsungan usaha UMKM. (Warsono, 2009 dalam Kurniawati, dkk., 2012). Pada sebagian besar yuridiksi, undang-undang mewajibkan semua atau sebagian UKM untuk menyiapkan laporan keuangan dan seringkali memintanya untuk diaudit. Biasanya, laporan keuangan diajukan ke pemerintah, di 
publikasikan pada suatu situs web atau tersedia berdasarkan permintaan (European Commision, 2008 dalam Kwaak, et al., 2009).

Berdasarkan kondisi tersebut di atas, Dewan Standar Akuntansi Keuangan (DSAK) menerbitkan Standar Akuntansi Keuangan untuk Entitas Tanpa Akuntabilitas Publik (SAK ETAP) dan standar ini berlaku efektif per 1 Januari 2011. SAK ETAP merupakan salah satu standar keuangan yang ditetapkan untuk mempermudah UMKM dalam menyusun dan menyajikan laporan keuangan yang lebih informatif dengan tujuan memberikan kemudahan bagi investor maupun kreditor untuk memberikan bantuan pembiayaan bagi para pengusaha UMKM. Salah satu dampak dari penerapan SAK ETAP pada UMKM adalah terjadinya peningkatan dalam efisiensi, efektivitas dan produktivitas usaha. Selanjutnya perusahaan kecil dan menengah diharapkan dapat menyusun laporan keuangannya sendiri, dapat diaudit dan mendapatkan opini audit, sehingga perusahaan dapat menggunakan laporan keuangannya untuk mendapatkan dana atau modal untuk pengembangan usahanya. (Martani, 2011 dalam Seran, 2017).

Namun pada kenyataannya, pencatatan keuangan yang dilakukan UMKM di Indonesia masih jauh dari SAK ETAP. Darmayanti, dkk. (2017) dalam penelitiannya menyatakan bahwa pencatatan yang dilakukan oleh UMKM Pengrajin Endek Mastuli “Ayu Lestari” di Kecamatan Buleleng masih belum sesuai dengan pedoman penyusunan laporan keuangan berdasarkan SAK ETAP dimana UMKM tersebut hanya menyusun laporan pembayaran piutang saja. Ketidakmampuan pemilik dalam melakukan pencatatan yang benar disebabkan oleh kurangnya pengetahuan pemilik terhadap bagaimana laporan keuangan yang 
sesuai dengan usaha pemilik. Salmiah, dkk., (2015) dalam penelitiannya juga mengungkapkan bahwa bentuk penerapan akuntansi pada UMKM Kecamatan Sukajadi Binaan Dinas Koperasi dan UMKM Kota Pekanbaru rata-rata belum sesuai dengan SAK ETAP.

Fenomena ini juga terjadi di Negara-negara lainnya. Uyar dan Güngörmüş (2013) melakukan studi pada UKM di Turki mengenai keefektifan penerapan dari IFRS (international financial reporting standards) atau standar pelaporan keuangan internasional bagi UKM. Hasil penelitian menunjukkan bahwa sebagian besar UKM di Turki sangat mendukung adanya standar akuntansi yang dikhususkan untuk UKM ini, namun kendala yang terjadi adalah sebagian besar pengusaha di Turki masih belum memahami beberapa hal yang terdapat dalam standar tersebut karena kurangnya keterampilan dan pelatihan yang diterima oleh para staf bagian akuntansi. Maseko dan Manyani (2011) dalam penelitiannya juga mengungkapkan bahwa mayoritas UKM di Zimbabwe tidak menyimpan catatan akuntansi yang lengkap karena kurangnya pengetahuan akuntansi dan akibatnya terdapat ketidakefisienan penggunaan informasi akuntansi dalam pengukuran kinerja keuangan. Perera dan Chand (2015) melakukan studi yang memberikan bukti bahwa IFRS untuk UKM telah menjadi tantangan bagi entitas tanpa akuntabilitas publik untuk diadopsi. IFRS untuk UKM dikembangkan untuk memenuhi kebutuhan pelaporan UKM di seluruh dunia, tetapi Schutte dan Buys (2011) dalam penelitiannya mengungkapkan bahwa sebagian besar responden dari standar akuntansi yang dikhususkan untuk UKM ini hanya berasal dari Eropa dan negara-negara maju lainnya dan hanya sebagian kecil responden yang berasal dari 
Afrika dan negara-negara berkembang lainnya. European Commission (2008) mengungkapkan bahwa informasi akuntansi yang tepat sangat penting untuk keberhasilan pengelolaan suatu entitas bisnis baik besar maupun kecil. Akan tetapi berdasarkan realita, UKM tidak memiliki keterampilan dan infrastruktur akuntansi yang baik untuk menerapkan peraturan dan standar akuntansi (Dang-Duc, 2011). Melihat pentingnya penerapan SAK ETAP bagi UMKM serta masih minimnya penerapan dari SAK ETAP pada UMKM, maka peneliti tertarik untuk melakukan penelitian mengenai SAK ETAP.

Berdasarkan data dari Dinas Koperasi dan UMKM Kota Denpasar (2017), jumlah UMKM di Kota Denpasar khususnya sektor perdagangan berjumlah 8,050 usaha pada tahun 2015 dimana jumlah ini adalah jumlah terbesar diantara sektor lainnya (sektor pertanian, sektor non pertanian, dan sektor jasa) (www.ukmdenpasarkota.info/ukmdiskop.denpasarkota.go.id diakses tanggal 9 Juli 2017). Perusahaan dagang merupakan perusahaan yang kegiatan utamanya yaitu membeli dan menjual barang dagangan sehingga pendapatan pokoknya diperoleh dari penjualan barang dagangan. Persediaan barang dagangan merupakan unsur utama dari suatu perusahaan dagang. Masalah yang banyak dihadapi oleh perusahaan dagang yaitu ketidaksesuaian atau ketidakakuratan catatan persediaan dikarenakan sebagian besar perusahaan dagang tidak menggunakan sistem pengelolaan persediaan yang baik (DeHoratius, et al., 2008). Ketidakakuratan pencatatan persediaan ini salah satunya terjadi karena aspek perilaku pekerja. (Bruccoleri, et al., 2014). Faktor-faktor lain yang menyebabkan terjadinya ketidakakuratan catatan persediaan ini yaitu seperti lemahnya praktik audit 
inventaris, kompleksitas lingkungan toko serta struktur distribusi (DeHoratius dan Raman, 2008). Melihat banyaknya jumlah UMKM pada sektor perdagangan di Kota Denpasar serta masalah signifikan yang dialami oleh sebagian besar UMKM pada perusahaan dagang, maka peneliti tertarik untuk melakukan penelitian pada perusahaan dengan jenis usaha dagang untuk mengetahui bagaimana penerapan dari SAK ETAP ini pada perusahaan dagang.

PT. Aira Nusantara Indah merupakan perusahaan tanpa akuntabilitas publik yang yang bergerak dibidang perdagangan (membeli dan menjual barang dagangan) untuk bahan kimia pembersih (cleaning chemicals) dengan merek terdaftar “AIRA CARE”. PT. Aira Nusantara Indah beralamat di Jalan Dalung Permai K3/134, Kerobokan, Kuta, Bali, dan juga memiliki gudang persediaan barang dagangan di Jalan Gunung Andakasa Gang Mawar No. 11 Denpasar, Bali. Adapun beberapa produk dari "AIRA CARE" adalah berupa chemical tools dan chemical cleaning seperti air freshener, dust cleaner, floor care, furniture polish, hand soap, carbol fresh, multi purpose cleaner, deagreaser, dishwashing, neutral cleancer, dan lain sebagainya. Sasaran pemasaran produk dari PT. Aira Nusantara Indah sudah sangat luas yaitu mencakup villa-villa, hotel-hotel, serta berbagai instansi pemerintahan di Bali. Dalam perkembangannya PT. Aira Nusantara Indah terus melakukan perbaikan dan inovasi-inovasi, baik dari segi produk, promosi, pelayanan, distribusi dan lainnya, terbukti dari semakin banyaknya produk yang didistribusikan yaitu mencapai kurang lebih 105 jenis produk pada tahun 2016. Sejumlah strategi yang diterapkan bisa dikatakan sukses, terlihat dari semakin banyaknya konsumen yang mengenal PT. Aira Nusantara Indah, serta banyaknya 
permintaan konsumen terhadap produk-produk chemical cleaning ini dan bahkan menjadikan PT. Aira Nusantara Indah sebagai supplier tetap mereka.

Pada hasil observasi awal yang dilakukan peneliti pada PT. Aira Nusantara Indah, ditemukan permasalahan yaitu perusahaan tidak membuat laporan keuangan, sehingga penyajian laporan keuangan tidak sesuai dengan SAK ETAP. Perusahaan hanya melakukan pencatatan keuangan yang dibuat hanya berdasarkan pemahaman pemilik usaha. Adapun catatan keuangan yang dibuat oleh PT. Aira Nusantara Indah adalah sebagai berikut: 1). Catatan Pengeluaran dan Penerimaan Kas. PT. Aira Nusantara Indah melakukan pencatatan kas setiap hari. Hal ini bertujuan untuk mengetahui transaksi pengeluaran dan pemasukan kas yang dilakukan. Kemudian catatan pengeluaran dan penerimaan kas ini akan direkap setiap bulannya untuk mengetahui seluruh transaksi yang terjadi; 2) Catatan Penjualan. PT. Aira Nusantara Indah melakukan pencatatan secara menyeluruh setiap kali terjadi transaksi pembelian dari pelanggan. Dalam catatan penjualan ini, pemilik menuliskan nama pelanggan dan juga detail pesanan pelanggan untuk nantinya dibuatkan faktur penjualan. Catatan penjualan ini kemudian akan direkap perbulannya untuk mengetahui detail penjualan; 3) Kartu Piutang, berfungsi untuk mengetahui jumlah pelanggan dan saldo piutang masing masing pelanggan serta total piutang seluruh pelanggan. PT. Aira Nusantara Indah juga membuat register piutang (kartu piutang), dimana dalam catatan ini pemilik mencantumkan penjualan secara detail, seperti pada catatan penjualan. Pada catatan ini dilengkapi kolom saldo piutang dari periode sebelumnya sehingga pada saat pelanggan melunasi hutangnya akan dicantumkan tanggal pembayaran hutang 
tersebut, dan kemudian catatan tersebut akan dihapus pada bulan berikutnya karena sudah dianggap lunas. Catatan penjualan ini kemudian akan direkap perbulannya untuk mengetahui detail pelunasan piutang; 4) Kartu Persediaan Barang, berfungsi untuk mengetahui jumlah awal dan akhir persediaan, dan juga untuk mengetahui tanggal masuk dan keluarnya suatu barang. Perusahaan menggunakan metode MPKP (masuk pertama keluar pertama) dimana barang yang pertama kali masuk akan dijual terlebih dahulu. Kartu persediaan ini diperbaharui setiap bulannya; 5) Laporan Laba Rugi; dibuat untuk mengetahui apakah perusahaan tersebut mengalami keuntungan atau kerugian. Untuk mengetahui laba atau rugi penghitungannya dilakukan dengan menjumlahkan semua pendapatan yang diterima kemudian dikurangi dengan biaya-biaya yang dikeluarkan selama periode satu tahun. Laporan laba rugi ini dibuat berdasarkan catatan penjualan, catatan penerimaan dan pengeluaran kas, dan catatan stok persediaaan barang dagangan. Dalam pembuatan laporan laba rugi pada tahun 2015, perusahaan hanya mengungkapkan sebagian transaksi dikarenakan terdapat beberapa transaksi yang tidak memiliki faktur penjualan.

Permasalahan berikutnya yaitu sering terjadinya perbedaan jumlah persediaan barang di gudang dengan jumlah persediaan pada kartu persediaan barang yang dibuat oleh perusahaan. Hal ini dikarenakan kurang lengkapnya informasi yang disajikan dalam catatan persediaan tersebut. PT. Aira Nusantara Indah juga mengalami masalah dalam penafsiran beban operasi dan beban penyusutan. Beban (expenses) merupakan hasil dari penggunaan aset atau jasa dalam proses menghasilkan pendapatan (Reeve, dkk., 2009). Sistem pencatatan 
pada PT. Aira Nusantara Indah masih jauh dari SAK ETAP serta tidak mampu mengungkapkan kondisi keuangan perusahaan dalam bentuk laporan keuangan.

Hasil penelitian ini diharapkan dapat memberikan gambaran perlakuan akuntansi pada perusahaan serta menggambarkan bagaimana SAK ETAP diterapkan pada PT. Aira Nusantara Indah. Hasil penelitian ini juga diharapkan dapat memberikan informasi yang berguna bagi PT. Aira Nusantara Indah sebagai masukan untuk meningkatkan kinerja dan menentukan suatu strategi perusahaan khususnya dalam mengoptimalkan fungsi dan peranan informasi.

\section{METODE PENELITIAN}

Lokasi penelitian dilakukan di PT. Aira Nusantara Indah yang beralamat di Jalan Dalung Permai Blok E No.13, Kabupaten Badung, Provinsi Bali. Adapun objek penelitian dalam penelitian ini adalah penerapan standar akuntansi keuangan entitas tanpa akuntabilitas publik (SAK ETAP) dari PT. Aira Nusantara Indah. Dalam penelitian ini, metode pengumpulan data yang digunakan adalah dengan observasi, dokumentasi, wawancara, dan studi pustaka. Jenis data yang digunakan dalam penelitian ini adalah data kualitatif dan data kuantitatif. Data kualitatif yang dipergunakan adalah gambaran umum dari PT. Aira Nusantara Indah, struktur organisasi PT. Aira Nusantara Indah beserta job description masing-masing. Sedangkan, data kuantitatif yang dipergunakan adalah data mengenai pencatatan akuntansi (laporan keuangan) dari PT. Aira Nusantara Indah. Sumber data yang digunakan dalam penelitian ini adalah data primer dan data sekunder. Adapun data primer yang digunakan dalam penelitian ini adalah hasil wawancara 
mendalam kepada pihak PT. Aira Nusantara Indah, dan data sekunder yang digunakan yaitu laporan keuangan dari PT. Aira Nusantara Indah.

Teknik analisis data yang dilakukan adalah analisis data kualitatif dengan metode deskriptif komparatif. Analisis data kualitatif merupakan proses pelacakan dan pengaturan secara sistematis catatan lapangan dan bahan-bahan lain yang dikumpulkan untuk meningkatkan pemahaman terhadap bahan-bahan tersebut agar dapat diinterpretasikan temuannya kepada orang lain. Analisis deskriptif dilakukan dengan cara mendiskripsikan laporan keuangan yang berada pada perusahaan, mengevaluasi, menganalisis serta memberi rekomendasi tentang pencatatan keuangan dan pembuatan laporan keuangan yang sesuai dengan SAK ETAP. Analisis data yang dilakukan terdiri dari mengumpulkan data, mereduksi data, menyajikan data, serta menarik kesimpulan/verifikasi data (Miles dan Huberman, 2007:16).

\section{HASIL DAN PEMBAHASAN}

PT. Aira Nusantara Indah merupakan perusahaan yang bergerak dalam bidang perdagangan, yang dalam pelaksanaanya pemilik dibantu oleh tiga orang karyawan. Aktivitas usaha yang dilakukan oleh PT. Aira Nusantara Indah meliputi penjualan bahan-bahan dan alat-alat chemical dan juga menerima pesanan pengadaan barang suatu instansi. Kegiatan dimulai dari membeli bahan-bahan untuk persediaan barang dagangan dan kemudian mendistribusikan pesanan kepada pelanggan. Dalam pelaksanannya, pemilik melakukan sendiri proses pembelian dan pendistribusian barang dagangannya. Apabila pemilik sudah tidak dapat menangani pekerjaan tersebut sendirian, barulah pemilik memperkerjakan 
karyawan untuk pendistribusian barang dagangan. Kemudian dalam hal pencatatan barang masuk dan barang keluar, hingga pencatatan kas masuk, kas keluar, serta piutang, seluruhnya di catat langsung oleh pemilik. Pemilik mengaku sempat memilliki pegawai untuk mencatat keuangan perusahaan, namun sering terjadi kesalahan yang dilakukan sehingga pemilik tidak percaya jika pekerjaan mengenai keuangan ini dilimpahkan kepada orang lain.

Penerapan pencatatan akuntansi yang dilakukan oleh PT. Aira Nusantara Indah dapat dikatakan masih sangat sederhana dan manual. Pencatatan hanya dilakukan sebatas untuk mengetahui berapa besar pengeluaran seperti pembelian barang dagangan, pembayaran hutang, penggajian dan lainnya, dan juga untuk mengetahui besar pemasukan berupa penambahan kas atau modal dari pemilik perusahaan serta penjualan dari bahan-bahan dan alat-alat chemical. Perusahaan sudah melakukan perlakuan akuntansi dalam hal pencatatan dengan membuat jurnal khusus yang didesain untuk perusahaan. Adapun catatan yang dibuat PT. Aira Nusantara Indah meliputi catatan penerimaan dan pengeluaran kas, catatan piutang, catatan penjualan, dan kartu persediaan barang dagangan.

Penggunaan SAK ETAP sebagai standar akuntansi keuangan mempunyai tujuan yaitu untuk mempermudah entitas dalam menyajikan laporan keuangannya. PT. Aira Nusantara Indah dalam hal ini belum sepenuhnya menerapakan SAK ETAP dalam penyajian laporan keuangannya. Perusahaan hanya membuat satu laporan keuangan yaitu laporan laba rugi pada tahun 2015 yang sudah menggunakan SAK ETAP, namun kesesuaian antara SAK ETAP dengan laporan keuangan PT. Aira Nusantara Indah tetap harus diperhatikan. Dalam hal ini 
digunakan metode analisis komparatif atau analisa perbandingan dengan cara membandingkan penyajian laporan keuangan PT. AiraNusantara Indahdengan peraturan penyajian laporan keuangan menurut SAK ETAP untuk melihat kesesuaiannya. Perbandingan penyajian laporan keuangan menurut SAK ETAP dan laporan keuangan PT. Aira Nusantara Indah disajikan pada Tabel 1 sebagai berikut.

Tabel 1.

Perbandingan Penyajian Laporan Keuangan Menurut SAK ETAP dengan Penyajian Laporan Keuangan PT. ANI

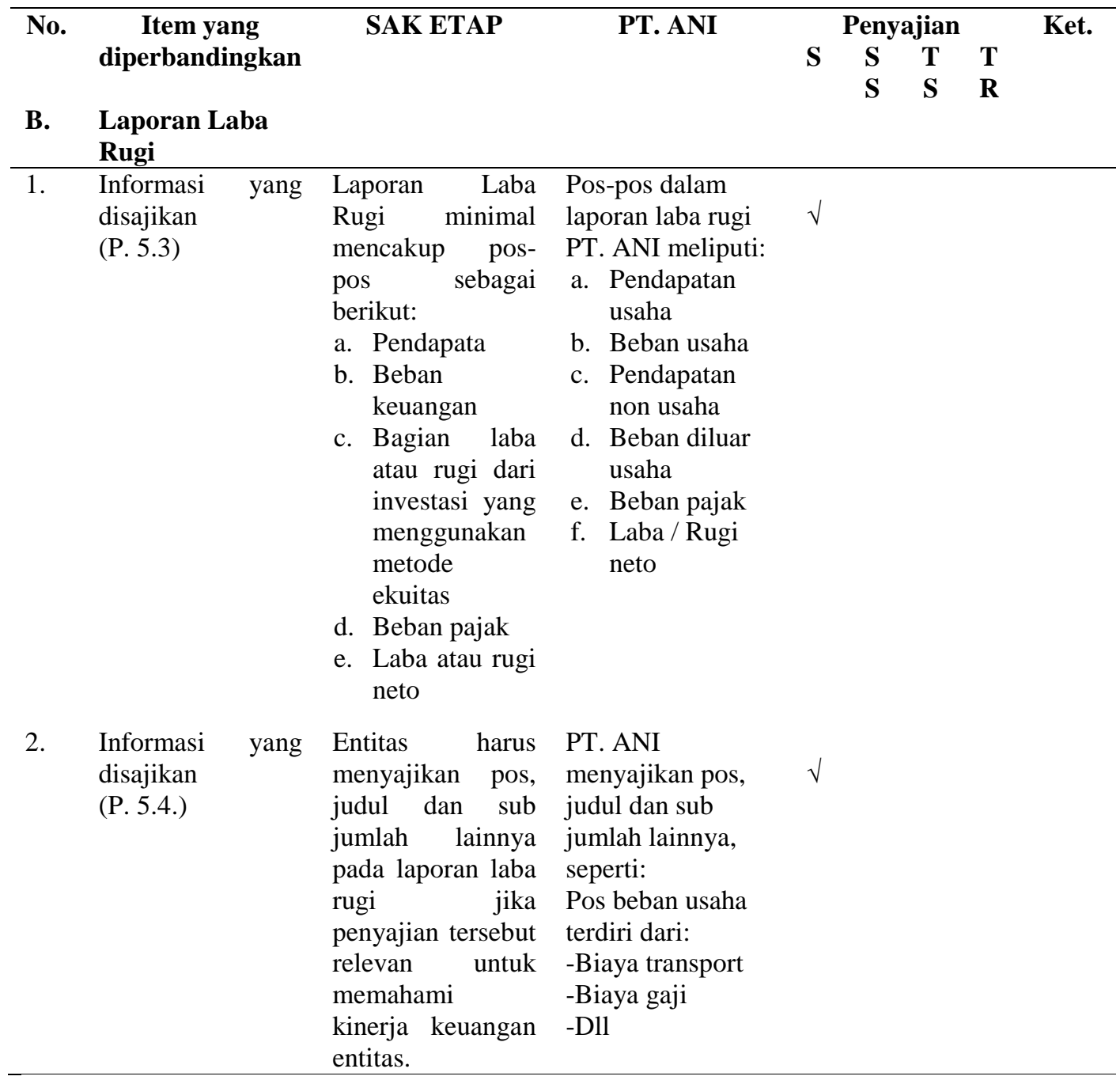


Keterangan:

$\mathrm{S} \quad=$ Sesuai

SS = Sesuai Sebagian

TS = Tidak Sesuai

TR = Tidak Relevan

PT. Aira Nusantara Indah dalam sistem pencatatannya masih menggunakan sistem single entry atau pembukuan karena pencatatan laporan keuangan dicatat berdasarkan pengetahuan pemilik yang hanya mengetahui pencatatan dengan sistem single entry. Pengambilan keputusan yang dilakukan PT. Aira Nusantara Indah berdasarkan kebijakan dari pemilik. Pegawai perusahaan, dalam hal ini pegawai bagian administratif tidak dapat langsung mengambil keputusan dari catatan keuangan dikarenakan kurangnya informasi yang mendetail yang terdapat dalam catatan keuangan tersebut sehingga pengambilan keputusan dilakukan hanya berdasarkan kebijakan pemilik. Pencatatan yang dilakukan oleh PT. Aira Nusantara Indah sudah memenuhi prinsip akuntabilitas.

Secara sederhana siklus akuntansi merupakan suatu pencatatan transaksi keuangan yang terjadi dalam satu periode secara berulang - ulang atau rutin. Kegiatan yang merupakan alur siklus akuntansi ialah tahap pengidentifikasian, tahap pencatatan, tahap pengikhtisaran serta tahap pelaporan. Tahap pencatatan terdiri dari pembuatan atau penerimaan bukti transaksi, pencatatan dalam jurnal, serta pemindahbukuan ke buku besar. PT. Aira Nusantara Indah selama ini sudah melakukan pencatatan atas transaski dengan pembuatan jurnal khusus dalam proses penyusunan laporan keuangannya. Meskipun dalam pencatatanya sudah bagus, tetapi sistem pencatatan yang dibuat oleh perusahaan masih kurang efektif dan efisien, dan masih belum sesuai dengan sistem akuntansi yang ada. 
Pencatatan transaksi dan kegiatan akuntansi PT. Aira Nusantara Indah menggunakan cash basis dimana hal ini dapat membuat laporan keuangan akan semakin mengalami kesalahan nilai nominal dari beberapa akun-akun yang ada. Hal ini tidak sesuai dengan SAK ETAP yang mengharuskan menggunakan accrual basic.

Aktivitas utama perusahaan dagang adalah melakukan pengadaan barang dagangan dengan tujuan untuk dijual kembali, dengan kata lain aktivitas utamanya adalah pembelian dan penjualan. Kedua jenis transaksi ini merupakan bagian terbesar dari transaksi-transaksi perusahaaan pada setiap harinya. Semakin besar sebuah perusahaan dagang, semakin banyak pula kedua transaksi tersebut terjadi, sehingga menjadi tidak praktis lagi kalau harus direkam menggunakan jurnal umum. Dengan berpedoman pada transaksi-transaksi yang sering terjadi pada perusahaan dagang berskala menengah, maka jurnal-jurnal khusus yang diperlukan oleh sebuah perusahaan dagang adalah sebagai berikut: (1) Jurnal pembelian: mencatat pembelian secara kredit; (2) Jurnal pengeluaran kas: mencatat pengeluaran kas; (3) Jurnal penjualan: mencatat penjualan secara kredit; (4) Jurnal penerimaan kas: mencatat penerimaan kas; dan (5) Jurnal memorial atau jurnal umum: mencatat transaksi-transaksi lainnya. Berdasarkan data keuangan yang dimiliki perusahaan, maka peneliti memiliki rekomendasi sesuai dengan SAK ETAP yaitu dengan membuat jurnal khusus yang dipakai untuk mencatat transaksi-transaksi khusus yang terjadi pada perusahaan. Adapun manfaat dari penerapan jurnal khusus diantaranya kemudahan pencatatan secara sistematis, mempercepat proses data transaksi, menyajikan data lebih cepat dan 
jelas, mempermudah proses pemostingan ke buku besar, serta memudahkan pemeriksaan secara berkala. Jurnal khusus yang direkomendasikan yaitu berupa jurnal pembelian, jurnal pengeluaran kas, jurnal penjualan, jurnal penerimaan kas, dan jurnal umum.

Menurut Suharli (2006) tahapan pengikhtisaran antara lain: (1) jurnal penyesuaian; (2) jurnal pembalik; dan (3) neraca lajur. Soemarso (2004) menyatakan bahwa jurnal penyesuaian perlu dibuat agar akun - akun yang ada mencerminkan keadaan aktiva, kewajiban, beban, pendapatan, dan modal yang sebenarnya. PT. Aira Nusantara Indah dalam hal ini belum mencatat jurnal penyesuaian sehingga mereka tidak memiliki jurnal penyesuaian yang sesuai dengan SAK ETAP.

Pengakuan akun-akun pada laporan posisi keuangan di PT. Aira Nusantara Indah sebagian besar sudah sesuai dengan SAK ETAP. Pada bagian aset lancar yakni kas dan setara kas, perusahaan belum membuat neraca pada laporan keuangannya sehingga kas dan setara kas di catat pada catatan kas. Pengakuan kas dan setara kas menurut SAK ETAP harus diakui di dalam neraca, sehingga pengakuan kas dan setara kas pada PT. Aira Nusantara Indah belum sesuai dengan SAK ETAP. Terkait persediaan, PT. Aira Nusantara Indah sudah mengakui persediaan pada catatan keuangannya. Persediaan dicatat pada register stock atau kartu persediaan barang dagangan, dimana kartu ini dilengkapi dengan jenis persediaan, jumlah persediaan, harga pokok persediaan, harga jual persediaan, tanggal masuk persediaaan dan tanggal keluar persediaan. PT. Aira Nusantara Indah dalam hal ini sudah memenuhi prinsip pengakuan dari persediaan. 
Pengakuan aset tetap dari PT. Aira Nusantara Indah adalah dengan cara mencatat semua aset tetap pada buku laporan aset yang sudah dibuatnya berdasarkan uang yang dikeluarkan untuk membeli aset tersebut. Pengakuan aset yang di lakukan PT. Aira Nusantara Indah sudah sesuai dengan SAK ETAP dengan mencatatnya sesuai dengan besarnya uang saat dilakukan pembelian. Terkait kewajiban, PT. Aira Nusantara Indah melakukan pencatatan hutang dengan mencatatnya pada catatan hutang. Kewajiban yang dilakukan berkaitan dengan kebutuhan perusahaan, dan kewajiban dihitung berdasarkan kas yang diterima maupun kas yang dikeluarkan untuk kewajiban. Pengakuan hutang dari PT. Aira Nusantara Indah sudah sesuai dengan SAK ETAP, akan tetapi perusahaan belum mengakui hutang tersebut didalam neraca. Pada ekuitas, PT. Aira Nusantara Indah tidak mencatat modal awal dalam laporan keuangannya, sehingga modal awal pada saat perusahaan didirikan pada tahun 2010, tidak diketahui berapa besarnya. Perusahaan hanya mencatat modal pada saat pendirian perseroan terbatas, yang jumlahnya sesuai dengan akta pendirian perusahaan.

Pengukuran akun-akun pada laporan posisi keuangan di PT. Aira Nusantara Indah sebagian besar sudah sesuai dengan SAK ETAP. PT. Aira Nusantara Indah mengukur kas dan setara kas dalam laporan keuangan berdasarkan pencatatan nominal dari akun - akun yang tersedia pada laporan keuangan dengan dicatat sebesar harga perolehan dengan lebih rinci berdasarkan jumlah seluruh nominal. Menurut SAK ETAP, dasar pengukuran yang umum adalah biaya historis dan nilai wajar. Terkait persediaan, PT. Aira Nusantara Indah mencatat akun persediaan pada catatan keuangannya, dimana persediaan dicatat pada register 
stock atau kartu persediaan barang dagangan. Pengukuran untuk persediaan dilakukan berdasarkan harga perolehan saat pembelian barang dagangan. Pengukuran persediaan yang dilakukan PT. Aira Nusantara Indah sudah sesuai dengan yang dijelaskan oleh SAK ETAP yaitu diukur sebesar biaya perolehan. Pengukuran pada akun aset tetap yang di lakukan PT. Aira Nusantara Indah untuk mengetahui besarnya nilai suatu aset adalah dengan mencatatnya sesuai dengan harga perolehan. Pengukuran aset tetap yang dilakukan oleh PT. Aira Nusantara Indah sudah sesuai dengan yang dijelaskan oleh SAK ETAP. Pengukuran pada akun hutang yang dilakukan PT. Aira Nusantara Indah untuk menetapkan nilai nominalnya adalah dengan mengukur akun hutang berdasarkan jumlah kas yang masuk. Dalam hal ini, pencatatan yang dilakukan oleh PT. Aira Nusantara Indah diukur berdasarkan nilai historis sebesar harga perolehan saat transaksi dilakukan. Menurut SAK ETAP kewajiban dicatat sebesar kas atau setara kas yang diterima atau sebesar nilai wajar dari aset non-kas yang diterima sebagai penukar dari kewajiban pada saat terjadinya kewajiban, sehingga pengukuran kewajiban yang dilakukan oleh PT. Aira Nusantara Indah sudah benar dan sesuai dengan SAK ETAP. Pada ekuitas, PT. Aira Nusantara Indah tidak mengukur besarnya modal yang disetor diawal, sehingga besarnya modal saat perusahaan berdiri tidak diketahui. Dalam pelaksanaannya, modal dari PT. Aira Nusantara Indah berasal dari dana pribadi pemilik. Pencatatan modal hanya dilakukan pada saat pendirian perseroan terbatas.

Penyajian laporan keuangan menyajikan dengan wajar posisi keuangan, kinerja keuangan, dan arus kas suatu entitas. Penyajian wajar mensyaratkan 
penyajian jujur atas pengaruh transaksi, peristiwa dan kondisi lain yang sesuai dengan definisi dan kriteria pengakuan aset, kewajiban, penghasilan dan beban. Pengakuan dari data laporan keuangan PT. Aira Nusantara Indah antara lain catatan kas, catatan hutang, dan laporan aset harus di akui dalam neraca. Pada kasus ini PT. Aira Nusantara Indah belum membuat neraca pada laporan keuangannya, sehingga peneliti merekomendasikan neraca yang sesuai dengan SAK ETAP dengan metode accrual basis.

Pengakuan akun-akun pada laporan laba rugi sebagian tidak sesuai dengan SAK ETAP. PT. Aira Nusantara Indah tidak mencatat pendapatan pada laporan laba rugi. Pendapatan hanya dicatat pada catatan pengeluaran dan penerimaan kas. Pelunasan piutang diperbaharui pada register piutang. Terkadang terjadi perbedaan antara pencatatan yang terdapat pada catatan pengeluaran dan penerimaan kas dengan catatan piutang. SAK ETAP menjelaskan bahwa laporan laba rugi memasukkan semua pos penghasilan dan beban yang diakui dalam suatu periode kecuali SAK ETAP mensyaratkan lain. Pengakuan yang dilakukan PT. Aira Nusantara Indah tidak sesuai dengan SAK ETAP karena pendapatan tidak dimasukkan pada laporan laba rugi. PT. Aira Nusantara Indah juga tidak mencatat beban pada laporan laba rugi, melainkan hanya mencatat pada catatan penerimaan dan pengeluaran kas. Pada pelaksanaannya PT. Aira Nusantara Indah sudah membuat catatan mengenai penyusutan aktiva berupa peralatan yang dimiliki, namun hal tersebut masih belum diperhitungkan (dibebankan) sehingga perhitungan laba menurut pemilik hanya sebatas pembayaran dikurangi bebanbeban riil. SAK ETAP menjelaskan bahwa pengakuan beban merupakan akibat 
langsung dari pengakuan aset dan kewajiban. Beban diakui dalam laporan laba rugi jika penurunan manfaat ekonomi masa depan yang berkaitan dengan penurunan aset atau peningkatan kewajiban telah terjadi dan dapat diukur secara andal. PT. Aira Nusantara Indah mencatat beban pada laporan laba rugi untuk mengurangi pendapatan yang mengakibatkan berkurangnya nilai pendapatan, sehingga pengakuan beban yang dilakukan PT. Aira Nusantara Indah sesuai dengan SAK ETAP, akan tetapi belum dimasukkan pada laporan laba rugi.

Pengukuran akun-akun pada laporan laba rugi di PT. Aira Nusantara Indah sudah sesuai dengan SAK ETAP. Pengukuran pendapatan PT. Aira Nusantara Indah dilakukan dengan menghitung jumlah kas yang didapat dari hasil penjualan. Dari aktivitas penjualan tersebut akan didapat sejumlah kas yang akan dicatat sebagai pendapatan. SAK ETAP menyatakan bahwa entitas harus mengukur pendapatan berdasarkan nilai wajar atas pembayaran yang diterima atau masih harus diterima. Nilai wajar tersebut tidak termasuk jumlah diskon penjualan dan potongan volume. PT. Aira Nusantara Indah sudah mengukur pendapatan berdasarkan nilai wajar dengan mengukur pendapatan atas pembayaran dan/atau dari penjualan yang diterima. Pengukuran beban PT. Aira Nusantara Indah adalah diukur dari besar kas atau setara kas yang dikeluarkan untuk akun beban. Dengan kata lain beban diukur berdasarkan nilai wajar dari pengeluaran yang dikeluarkan dari PT. Aira Nusantara Indah. Hal ini sesuai dengan definisi penyajian wajar menurut SAK ETAP yaitu penyajian yang jujur dari pengaruh transaksi, peristiwa dan kondisi lain yang memenuhi definisi dan kriteria pengakuan untuk aset, kewajiban, dan beban. Beban pada PT. Aira Nusantara Indah antara lain beban 
gaji karyawan, beban listrik air telepon, beban transport, beban pemeliharaan kendaraan, beban penyusutan peralatan, beban lain-lain, dan beban lainnya. Beban diakui pada laporan laba rugi dan diukur berdasarkan nilai wajar.

SAK ETAP mensyaratkan entitas untuk menyajikan laporan laba rugi untuk suatu periode yang merupakan kinerja keuangannya selama periode tersebut, serta informasi yang disajikan dalam laporan laba rugi dan bagaimana penyajiannya. Laporan laba rugi menyajikan penghasilan dan beban entitas untuk suatu periode. PT. Aira Nusantara Indah tidak membuat laporan laba rugi pada laporan keuangannya, sehingga tidak sesuai dengan SAK ETAP, maka peneliti merekomendasikan laporan laba rugi yang sesuai dengan SAK ETAP.

PT. Aira Nusantara Indah tidak membuat laporan arus kas, laporan laba rugi dan saldo laba, serta catatan atas laporan keuangan (CaLK), dikarenakan laporan keuangan yang di buat sebelumnya belum lengkap. Pemilik hanya melakukan tahapan pencatatan. Hal tersebut juga didasari dengan keterbatasan pengetahuan dari pemilik maupun karyawan dari PT. Aira Nusantara Indah tentang pembuatan laporan keuangan yang sesuai dengan SAK ETAP. Maka dari itu peneliti merekomendasikan pembuatan laporan keuangan lengkap yang sesuai dengan SAK ETAP.

Berdasarkan penelitian yang telah dilakukan dan pemaparan penjelasan diatas, terdapat beberapa hal yang menjadi kendala yang dapat menghambat penerapan SAK ETAP pada laporan keuangan PT. Aira Nusantara Indah, yaitu: (1) Rendahnya atau terbatasnya pengetahuan serta pemahaman pemilik maupun karyawan administrasi terhadap SAK ETAP; (2) Sosialisasi yang kurang terkait 
Laporan Keuangan yang sesuai SAK ETAP oleh Ikatan Akuntan Indonesia (IAI); (3) Belum adanya pendampingan yang intensif terkait penerapan SAK ETAP oleh Kementerian Koperasi dan UKM setempat; (4) Tidak adanya pengawasan dari pihak-pihak yang berkepentingan terhadap laporan keuangan PT. Aira Nusantara Indah.

\section{SIMPULAN}

Berdasarkan hasil analisis dapat disimpulkan bahwa: (1) PT. Aira Nusantara Indah sudah melakukan proses pencatatan dengan membuat jurnal khusus yang terdiri atas Catatan Penerimaan dan Pengeluaran Kas, Catatan Piutang, Catatan Penjualan, dan Kartu Persediaan Barang Dagangan. Meskipun dalam pencatatannya sudah bagus, catatan yang dibuat oleh perusahaan ini belum sepenuhnya efektif dan efisien. Berdasarkan hal tersebut peneliti merekomendasikan jurnal khusus yang sesuai dengan kondisi perusahaan yang terdiri dari Jurnal Pembelian, Jurnal Penjualan, Jurnal Penerimaan Kas, Jurnal Pengeluaran Kas, dan Jurnal Umum; (2) Pengakuan dan pengukuran akun-akun laporan posisi keuangan dan akun-akun laba rugi sebagian besar sudah sesuai dengan SAK ETAP; (3) PT. Aira Nusantara Indah tidak membuat laporan keuangan, sehingga penyajian laporan keuangan tidak sesuai dengan SAK ETAP; (4) PT. Aira Nusantara Indah memiliki kendala dalam menerapkan SAK ETAP dalam penyusunan laporan keuangannya.

Berdasarkan hasil analisis dan simpulan, dapat diajukan beberapa saran untuk penelitian selanjutnya dan perusahaan. Pertama, dengan adanya rekomendasi laporan keuangan yang sesuai dengan SAK ETAP, maka diharapkan 
perusahaan dapat membuat laporan keuangan periode selanjutnya yang sudah sesuai dengan SAK ETAP, Menempatkan karyawan yang memiliki kompetensi dalam membuat laporan keuangan untuk menghindari kesalahan pencatatan dan menghindari tercampurnya keuangan perusahaan dan keuangan pribadi, Mengikuti sosialisasi dari Ikatan Akuntan Indonesia (IAI) apabila terdapat kegiatan terkait yang memberikan pemahaman tentang SAK ETAP kepada UMKM sehingga laporan keuangan yang perusahaan buat akan sesuai dengan standar. Kedua, bagi peneliti selanjutnya diharapkan dapat menemukan objek atau jenis perusahaan yang berbeda sehingga dapat merekomendasikan laporan keuangan sesuai SAK ETAP pada UMKM yang lain.

\section{REFERENSI}

Baas, Timo \& Mechthild Schrooten. 2005. Relationship Banking and SMEs A Theoretical Analysis. Discussion Papers 469.

Bruccoleri, Manfredi., Salvatore Cannella \& Giulia La Porta. 2014. Inventory record inaccuracy in supply chains: the role of workers' behavior. International Journal of Physical Distribution \& Logistics Management, 44(10), 796-819.

Dang-Duc, Son. 2011. Compliance with accounting standards by SMEs in transitional economies: evidence from Vietnam. Journal of Applied Accounting Research, 12(2), 96-107.

Darmayanti, Ni Putu Octavia Anggraini., Ni Nyoman Trisna Herawati \& I Gusti Ayu Purnamawati. 2017. Implementasi Penyusunan Laporan Keuangan Berdasarkan SAK-ETAP Dan Penilaian Kinerja Pada UMKM Pengrajin Endek Mastuli “Ayu Lestari” Di Desa Kalianget Kecamatan Buleleng. $e$ Journal S1 Ak Universitas Pendidikan Ganesha, 1.

DeHoratius, Nicole., Adam. J. Mersereau \& Linus Schrage. 2008. Retail Inventory Management When Records Are Inaccurate. Manufacturing \& Service Operations Management, 10(2), 257-277.

DeHoratius, Nicole \& Ananth Raman. 2008. Inventory Record Inaccuracy: An Empirical Analysis. Management Science, 54(4), 627-641. 
Dewan Standar Akuntansi Keuangan Ikatan Akuntansi Indonesia. 2016. SAK Standar Akuntansi Keuangan - Entitas Tanpa Akuntabilitas Publik. Jakarta: Grha Akuntan.

European Commission (Enterprise and Industry Directorate-General). 2008. Final Report of the Expert Group: Accounting System for small enterprisesRecommendations and good Practices.

IAI. 2009. Standar Akuntansi Keuangan. Jakarta: Salemba Empat.

Kementerian Koperasi dan UMKM. 2013. Data Usaha Mikro, Kecil, Menengah (UMKM) dan Usaha Besar (UB) Tahun 2012-2013. http://www.depkop.go.id/ Diunduh tanggal 1 bulan Mei tahun 2017.

Kurniawati, Elisabeth Penti., Paskah Ika Nugroho \& Chandra Arifin. 2012. Penerapan Akuntansi Pada Usaha Mikro Kecil Dan Menengah (UMKM). Informatics and Business Institute Darmajaya 10(2).

Kwaak, T., S. Wennekers, A. van Stel, C. Hartog, J. Snijders, J. Telussa, \& K. Bakker. 2009. European SMEs under Pressure: Annual Report on Small and Medium-sized Enterprises 2009. European Commission, 1-60.

Lucas, M., Malcolm Prowle, \& Glynn Lowth .2013. Management Accounting Practices of (UK) Small-Medium-Sized Enterprises (SMEs). Chartered Institute of Management Accountants, 9(4), 1-14.

Maseko, Nelson, \& Onias Manyani. 2011. Accounting Practices Of Smes In Zimbabwe: An Investigative Study Of Record Keeping For Performance Measurement (A Case Study Of Bindura). Journal of Accounting and Taxation, 3(8).

Perera, Dinuja dan Chand, Parmod. 2015. Issues in the adoption of international financial reporting standards (IFRS) for small and medium-sized enterprises (SMES). Advances in Accounting, 31(1), 165-178.

Pradipta, I Gusti Putu Ngurah Aditya, \& Ni Luh Supadmi. 2015. Pengaruh Persepsi Kemudahan Penggunaan Dan Kegunaan Pada Implementasi SAK ETAP (Studi Empiris Pada UKM Di Denpasar Utara). E-jurnal Akuntansi Universitas Udayana 13, 857-887.

Reeve, James M., Carl S. Warren, Jonathan E. Duchac, Ersa Tri Wahyuni, Gatot Soepriyanto, Amir Abadi Jusuf, \& Chaerul D. Djakman. 2009. Pengantar Akuntansi - Adaptasi Indonesia Buku 1. Jakarta: Penerbit Salemba Empat. 
Rosadi, Samsul. 2011. Analisis Bentuk-Bentuk Laporan Keuangan dan Efektivitas Laporan Keuangan Pada UMKM (Studi Kasus Pada UMKM Kelompok Pengerajin Kuningan di Kecamatan Juwana). Skripsi. Universitas Sebelas Maret Surakarta.

Rudiantoro, Rizki, \& Sylvia Veronica Siregar. 2012. Kualitas Laporan Keuangan UMKM serta Prospek Implementasi SAK ETAP. Jurnal Akuntansi Dan Keuangan Indonesia, 9(1), 1-21.

Sakti, Aden Lubang. 2017. Analisis Penerapan Standar Akuntansi Keuangan Entitas Tanpa Akuntabilitas Publik (SAK ETAP) Pada Usaha Mikro Kecil Dan Menengah (UMKM) (Studi Kasus Pada PT. Aira Nusantara Indah Di Blitar). Skripsi.Central Library of Maulana Malik Ibrahim State Islamic University of Malang.

Salmiah, Neneng., Indarti, \& Inova Fitri Siregar. 2015. Analisis Penerapan Akuntansi Dan Kesesuaiannya Dengan Standar Akuntansi Keuangan Entitas Tanpa Akuntabilitas Publik (Pada UMKM Di Kecamatan Sukajadi Binaan Diskop \& Umkm Kota Pekanbaru), Jurnal Akuntansi, Vol. 3, No. 2, April $2015: 212-226$

Seran, Adiutrix Maria Irayanti. 2017. Evaluasi Penyajian Laporan Keuangan Credit Union Berdasarkan Standar Akuntansi Keuangan Entitas Tanpa Akuntabilitas Publik ( SAK ETAP ) Revisi Tahun 2013. Perpustakaan Univesitas Sanata Dharma.

Schutte, Danie dan Buys, Pieter. 2011. A Critical Analysis of the Contents of the IFRS for SMEs - A South African Perspective. Sajems, 14(2), 188-209.

Sugiyono, Prof. Dr. 2014. Metode Penelitian Kuantitatif Kualitatif $R \& D$. Bandung: Alfabeta.

Suhairi. 2004. Personality, Accounting Knowledge, Accounting Information Usage and Performance: A Research On Enterpreneurship Of Indonesia Medium Industried. Disertasi, USM. Malaysia

Suharli, michell. 2006. Studi Empiris yang Berpengaruh Terhadap Ketetpatan Waktu Pelaporan Keuangan. Jurnal bisnis dan Akuntansi, Vol. 8, No. 1, Hal 34-55.

Tambunan, Tulus. 2012. Usaha Mikro Kecil dan Menengah di Indonesia. Edisi ke satu. LP3ES: Jakarta.

Thang, Le Chien, \& Truong Quang. 2005. Human Resource Management Practices In A Transitional Economy: A Comparative Study Of Enterprise Ownership Forms In Vietnam. Asia Pacific Business Review, 11(1), 25-47. 
UKM Binaan Dinas Koperasi Kota Denpasar. 2017. Data UKM Kota Denpasar Tahun 2015. http://ukmdenpasarkota.info/ukmdiskop.denpasarkota.go.id, diakses tanggal 9 Juli 2017.

Undang-Undang Republik Indonesia No. 20 Tahun 2008 tanggal 4 Juli 2008 tentang Usaha Mikro, Kecil, dan Menengah.

Uyar, Ali., \& Ali Haydar Güngörmüş. 2013. Perceptions And Knowledge Of Accounting Professionals On IFRS For Smes: Evidence From Turkey. Research in Accounting Regulation, 25(1), 77-87.

van Wyk, H. A. \& J. Rossouw, J. 2009. IFRS for SMEs in South Africa: a giant leap for accounting, but too big for smaller entities in general. Meditari Accountancy Research, 17(1), 99-116.

Wahdini \& Suhairi. (2006). Persepsi Akuntan Terhadap Overload Standar Akuntansi Keuangan (Sak) Bagi Usaha Kecil Dan Menengah. Simposium Nasional Akuntansi, 23-26. 